\title{
The role of two sediment-dwelling invertebrates on the mercury transfer from sediments to the estuarine trophic web
}

\author{
J.P. Coelho ${ }^{\mathrm{a}, *}$, M. Nunes ${ }^{\mathrm{b}}$, M. Dolbeth ${ }^{\mathrm{b}}$, M.E. Pereira ${ }^{\mathrm{a}}$, A.C. Duarte $^{\mathrm{a}}$, M.A. Pardal ${ }^{\mathrm{b}}$ \\ ${ }^{a}$ CESAM and Chemistry Department, University of Aveiro, Campus de Santiago, 3810-193 Aveiro, Portugal \\ ${ }^{\mathrm{b}}$ Zoology Department, IMAR -Institute of Marine Research, University of Coimbra, 3004-517 Coimbra, Portugal
}

Received 26 October 2007; accepted 21 January 2008

Available online 10 February 2008

\begin{abstract}
The annual total and organic mercury bioaccumulation pattern of Scrobicularia plana and Hediste diversicolor was assessed to evaluate the potential mercury transfer from contaminated sediments to estuarine food webs. S. plana was found to accumulate more total and organic mercury than $H$. diversicolor, up to $0.79 \mathrm{mg} \mathrm{kg}^{-1}$ and $0.15 \mathrm{mg} \mathrm{kg}^{-1}$ (wet weight) respectively, with a maximum annual uptake of $0.21 \mathrm{mg} \mathrm{kg}^{-1} \mathrm{y}^{-1}$, while for methylmercury the annual accumulation was similar between species and never exceeded $0.045 \mathrm{mg} \mathrm{kg}^{-1} \mathrm{y}^{-1}$. The higher organic mercury fraction in $H$. diversicolor is related to the omnivorous diet of this species. Both species increase methylmercury exposure by burrowing activities and uptake in anoxic, methylmercury rich sediment layers. Integration with the annual biological production of each species revealed mercury incorporation rates that reached $28 \mu \mathrm{g} \mathrm{m}^{-2} \mathrm{y}^{-1}$, and to extract as much as $11.5 \mathrm{~g} \mathrm{Hg} \mathrm{y}^{-1}$ (of which 95\% associated with $S$. plana) in the $0.4 \mathrm{~km}^{2}$ of the most contaminated area, that can be transferred to higher trophic levels. S. plana is therefore an essential vector in the mercury biomagnification processes, through uptake from contaminated sediments and, by predation, to transfer it to economically important and exploited estuarine species.
\end{abstract}

(C) 2008 Elsevier Ltd. All rights reserved.

Keywords: Hediste diversicolor; Scrobicularia plana; mercury; methylmercury; bioaccumulation; biological production

\section{Introduction}

Estuaries and coastal waters are considered among the most productive ecosystems on earth and are also among the most impacted by contaminants derived from anthropogenic activities, therefore being a concern to researchers, managers and policy makers (Usero et al., 2005; Moreira et al., 2006). Sediments are essential for the biogeochemical cycle of most contaminants, acting as source, sink and transformation center (Moreira et al., 2006). Mercury, considered as one of the most toxic contaminants to estuarine ecosystems (Tchounwou et al., 2003), is primarily associated to organic matter in oxidized sediments and with sulfides in anoxic environments (Wang et al., 1998). Hence, its availability to benthic fauna

\footnotetext{
* Corresponding author.

E-mail address: jpcoelho@ua.pt (J.P. Coelho).
}

will be affected both by sediment characteristics and by the specific physiology of each species (Wang et al., 1998).

Mercury toxicity is enhanced through methylation processes occurring in the sediments. Methylmercury is more toxic, bioavailable and prone to bioaccumulation and biomagnification in estuarine food webs, ultimately finding its way to species usually consumed by humans (Wang et al., 1998; Clarkson et al., 2003; Tchounwou et al., 2003). Despite methylmercury typically being below $1 \%$ of total mercury in sediments, levels in fish are commonly above $90 \%$, due to a higher biomagnification of the organic form (Lawson and Mason, 1998; Coelho et al., 2007).

The pathway of metal uptake is also of great interest, being essential to understand metal bioaccumulation and toxicity, and to assess the water and sediment quality criteria (Wang and Fisher, 1999). In the specific case of mercury, benthic organisms may be exposed trough the dissolved fraction, sediments and diet (Wang et al., 1998), the latter being essential 
for organisms at higher trophic levels. Wang et al. (1998) found that for a deposit-feeding polychaete, most mercury accumulation was derived from sediment ingestion, with the dissolved fraction assuming some relevance in methylmercury uptake. Taking into account that mercury levels are usually higher in sediments, there may be ecological implications for the environment, since sediment dwelling benthic invertebrates like $\mathrm{He}$ diste diversicolor and Scrobicularia plana are common dietary items for predatory species like crabs (Baeta et al., 2006), fish (Leitão et al., 2006) and birds (Lopes et al., 2006).

The clam Scrobicularia plana is a long-lived deposit-feeding bivalve species present in muddy to sandy sediments, with a wide geographical range (Verdelhos et al., 2005). It has a lifespan of 5 years, one annual recruitment period and growth rates of roughly $1 \mathrm{~cm} \mathrm{y}^{-1}$ (Verdelhos et al., 2005). This species was found to accumulate mercury linearly throughout its lifespan, with annual accumulation rates as high as $0.25 \mathrm{mg} \mathrm{kg}^{-1}$ (wet weight) highly correlated with mercury levels in suspended particulate matter (SPM), suggesting a dietary pathway for mercury accumulation (Coelho et al., 2006).

The ragworm Hediste diversicolor is considered as a key species in soft-bottom communities all over Europe. It is considered an omnivore and also a predator, but typically behaves as deposit feeder (Scaps, 2002; Moreira et al., 2006). The lifespan of this polychaete species ranges between 1.5 to 2 years, and in Southern Europe presents an annual growth rate of $\sim 6 \mathrm{~cm} \mathrm{y}^{-1}$ and two recruitment periods, in February and April/May (Abrantes et al., 1999; Scaps, 2002).

Hediste diversicolor has predominant impacts on sedimentary processes due to its ecological characteristics (burrowing depth, bio-irrigation activities and sediment reworking) and its feeding activities may be considered a rate-limiting step in detritus processing (Moreira et al., 2006). In contaminated areas, this will imply a decisive role in mercury mobilization and transfer from sediments and detritus to higher levels in the food chain, considering that this species is the main dietary item for several estuarine predators (Scaps, 2002). Some information on mercury accumulation by this species is available in literature (Muhaya et al., 1997; Coelho et al., 2007), where it was found to accumulate less mercury than Scrobicularia plana despite similar dietary strategies (Coelho et al., 2007). Nevertheless, mercury levels were not corrected for individual age and hence no direct comparison between the two species can be made. In a study on the closely related species Nereis virens, Miron et al. (1994) found that mercury induced changes in the ventilation behavior of the worms, and that this species had a long-term capacity for sustaining high levels of mercury concentrations, acclimating efficiently to contaminated sediments.

Taking into account that these two species are essentially deposit feeders and important prey items to higher trophic levels (Baeta et al., 2006; Leitão et al., 2006; Lopes et al., 2006), they must play an essential role in the mobilization of mercury from the sediments to biota, increasing the bioavailability of this contaminant. By calculating the annual production of these species, an estimation of the mercury amount removed from the sediments (otherwise not bioavailable), and accessible for trophic transfer to predators, will be possible. This quantification is essential for the clarification of the mercury biogeochemical cycle, and is yet to be accomplished. Therefore, the main objective of this research was to compare the annual mercury bioaccumulation pattern of these two species, both for total and organic mercury, and to integrate it with the annual secondary production (available for higher trophic levels) in order to assess the potential mercury transfer from highly contaminated sediments to economically important species.

\section{Methods}

\subsection{Study site}

The study was conducted in the Ria de Aveiro coastal lagoon, northwestern coast of Portugal (Fig. 1), that for 50 years received continuous mercury discharges from a chlor-alkali industry, which induced an environmental contamination gradient inside the lagoon (Pereira et al., 1998).

Fourteen sampling locations (A1-A14, Fig. 1) were selected along the four main arms of the lagoon, with special focus on the most contaminated area, the Laranjo Basin (stations A1-A5), in the vicinity of the industrial mercury discharges. In addition, one sampling station was selected in the Mondego estuary (A15), $60 \mathrm{~km}$ south from the Ria de Aveiro. This station was considered to near background concentrations of heavy metals (Vale et al., 2002) and served as a reference site for this study.

\subsection{Sampling procedures}

All samples were collected on a consecutive three-day sampling campaign in the summer of 2003, at equivalent tidal situations, except for the organism samples in location A1 that, due to mishandling and contamination in the laboratory, had to be recollected at a latter time. Sampling took place during low water conditions in order to assess the maximum potential contamination stress to organisms. At each site a composite sediment sample was obtained, consisting of five replicate sediment cores (20 cm deep) pooled together in order to account for within-site variability. Water samples were collected from intertidal water at each site in acid-washed PET bottles.

Biological samples were collected from the shoreline, and consisted of 10 individual replicates at each site and composite samples (for organic mercury analyses, a mass demanding procedure) of both Hediste diversicolor and Scrobicularia plana. Samples of $H$. diversicolor consisted of adult individuals (average age of 18 months) and bias related to reproduction was avoided by sampling outside the recruitment periods (February-May and September, Abrantes et al., 1999).

Sampling of Scrobicularia plana focused on 3-year-old adult individuals (about $3 \mathrm{~cm}$ shell width), the smallest commercially available individuals. Bias related to reproduction was avoided by sampling outside the spring recruitment period. All biological samples were left to depurate, freeze-dried at $-50{ }^{\circ} \mathrm{C}$ and 0.06 bar, and homogenized for analysis. 

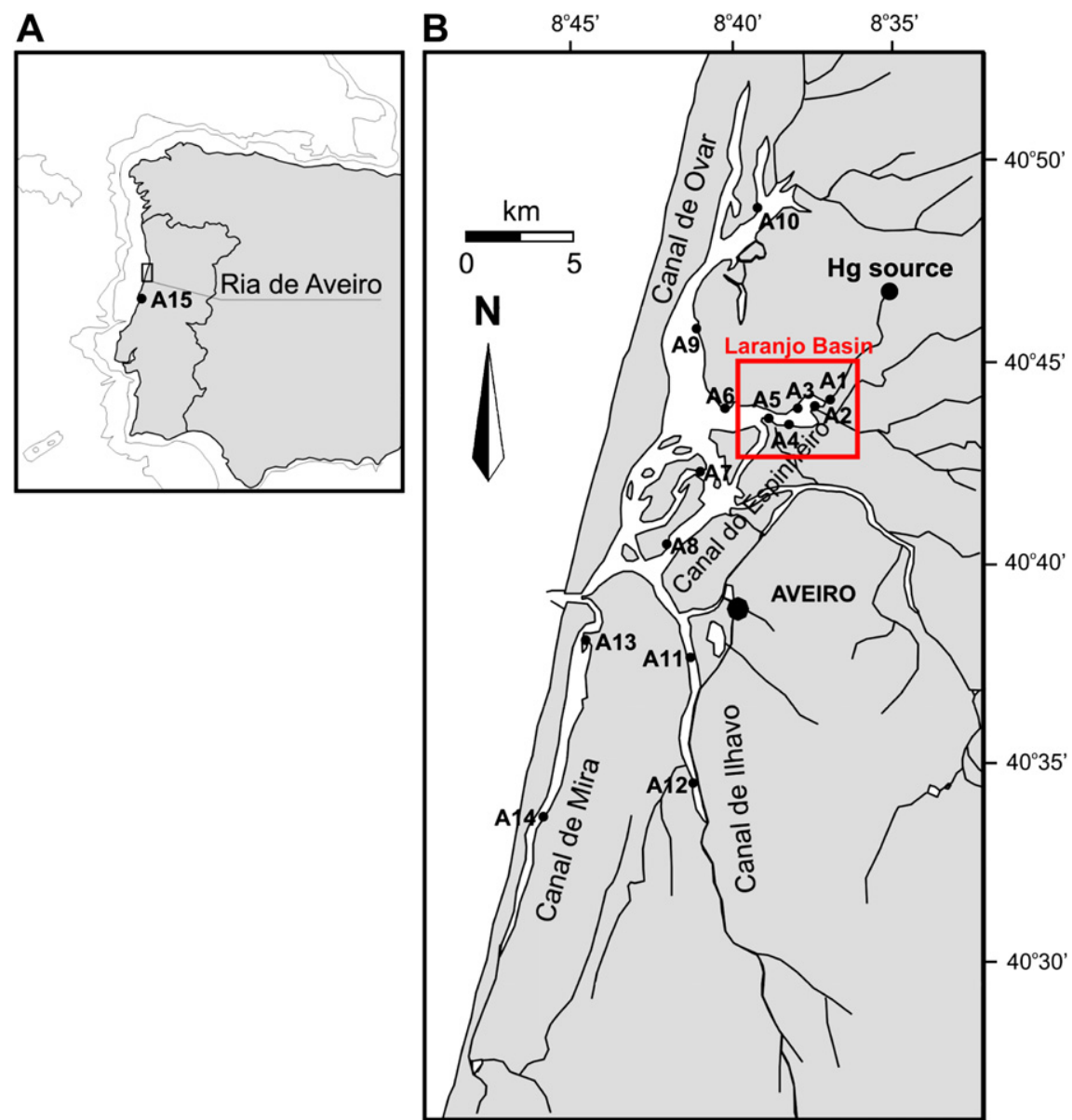

Fig. 1. The Ria de Aveiro coastal lagoon with the sampling sites indicated.

Sampling for production estimates consisted of two campaigns, one carried out in the winter and the other in summer. Both sampling campaigns were conducted on the mudflats during low water tide in four locations with distinct mercury contamination on the Ria de Aveiro coastal lagoon (sites A2, A5, A6/A7 and A10, from second most to least contaminated). At each site and sampling date, five random cores with $141 \mathrm{~cm}^{2}$ section were taken to a depth of $20 \mathrm{~cm}$. Samples were washed in estuarine water through a 500- $\mu \mathrm{m}$ mesh sieve bag. Later, organisms collected were separated, identified to the lowest possible taxonomic level and counted. Hediste diversicolor biomasses were determined as dry weight (DW) after oven drying at $60{ }^{\circ} \mathrm{C}$ for $72 \mathrm{~h}$. Scrobicularia plana specimens were measured under a dissecting microscope, using a calibrated eyepiece graticule for determination of shell length. Lengthweight regression (Verdelhos et al., 2005) was used to determine the ash free dry weight (AFDW), and weight-to-weight regression (Dolbeth et al., 2005) was used to determine DW. At each station and sampling date, salinity, temperature, $\mathrm{pH}$ and dissolved oxygen were measured in situ in low water pools.

\subsection{Laboratory procedures}

Sediments were air-dried for 3 days and then oven-dried overnight at $60{ }^{\circ} \mathrm{C}$, homogenized and sieved through a 1-mm sieve. Water samples were filtered on arrival to the laboratory, through $0.45-\mu \mathrm{m}$ Millipore cellulose acetate membrane filters, acidified with $\mathrm{HNO}_{3}$ (to lower the $\mathrm{pH}$ below 2) and stored at $4{ }^{\circ} \mathrm{C}$ until analysis. Filters were oven-dried at $60{ }^{\circ} \mathrm{C}$ and digested with $\mathrm{HNO}_{3} 4 \mathrm{~mol} \mathrm{~L}^{-1}$ for determination of the total mercury concentration in the suspended particulate fraction (SPM).

Sediment and biological samples were analyzed for total mercury by thermal decomposition atomic absorption spectrometry with gold amalgamation, using a LECO AMA-254 (Advanced Mercury Analyzer). Dissolved reactive mercury and suspended particulate matter (SPM) mercury analyses were performed by cold-vapor atomic fluorescence spectrometry (CV-AFS), using a PSA model Merlin 10.023 equipped with a detector PSA model 10.003, with tin chloride as reducing agent $(2 \%$ in $10 \% \mathrm{HCl})$. Organic mercury determinations in biological tissues were determined through digestion with a mixture of $18 \% \mathrm{KBr}$ in $5 \% \mathrm{H}_{2} \mathrm{SO}_{4}$, followed by extraction of organic mercury into toluene (for further details see Válega et al., 2006).

Analytical quality control was performed by using Certified Reference Materials (CRMs) IAEA-356 (efficiency: $91.9 \pm 5.9 \%$ at 0.05 significance level) and MESS-2 (efficiency: $79.7 \pm 3.8 \%$ at 0.05 significance level) for sediments and TORT-2 (lobster hepatopancreas) (efficiency: $99.8 \pm 7.6 \%$ at 0.05 significance level) and NIST-2976 
(mussel tissue) (efficiency: $98.0 \pm 8.3 \%$ at 0.05 significance level) for biota. The results were corrected according to the daily recovery percentage of repeated CRM analyses (to monitor changes in equipment sensitivity throughout the day). Reference material NIST-2976 was used for organic mercury analyses, and an extraction efficiency range of $87-98 \%$ was achieved.

\subsection{Secondary production}

Secondary production of Scrobicularia plana and Hediste diversicolor was estimated with the Brey (2001) method version 4-04 (worksheet provided in Brey, 2001; www.awibremerhaven.de/Benthic/Ecosystem/FoodWeb/Handbook/main. htm), considered the best alternative empirical method to estimate secondary production (Dolbeth et al., 2005). It was assumed that the mean between the summer and the winter individual and population biomasses (the biomass data available) would be representative of the annual mean biomasses needed for the computation of the secondary production. According to the recommendation of Dolbeth et al. (2005) no value was given to the depth, as species are intertidal. The weight-to-energy ratios needed for the application of the empirical method are provided in Brey (2001).

\section{Results}

\subsection{Environment}

Mercury in water (dissolved and suspended particulate matter) and total mercury in sediments were low (similar to the reference site A15) in most sampling stations, ranging from 0.05 to $0.35 \mathrm{mg} \mathrm{kg}^{-1}$ in sediments, 0.6 to $4 \mathrm{ng} \mathrm{L}^{-1}$ in the dissolved fraction and 0.4 to $1 \mathrm{mg} \mathrm{kg}^{-1}$ in SPM. However, in the most contaminated area (Laranjo Basin, stations A1-A5), concentrations reached as high as $50 \mathrm{mg} \mathrm{kg}^{-1}$ in sediments, $60 \mathrm{ng} \mathrm{L}^{-1}$ in water and $25 \mathrm{mg} \mathrm{kg}^{-1}$ in SPM (Fig. 2). Two distinct scenarios emerge in the Aveiro lagoon, where environmental mercury contamination problems seem therefore to be confined to the Laranjo Basin.

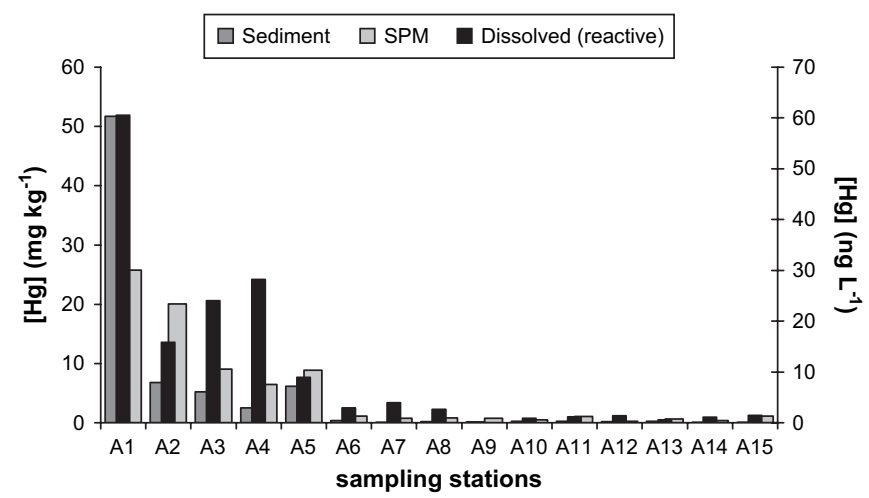

Fig. 2. Total mercury concentrations in sediment and suspended particulate matter $\left(\mathrm{mg} \mathrm{kg}^{-1}\right)$ and dissolved reactive mercury $\left(\mathrm{ng} \mathrm{\textrm {L } ^ { - 1 }}\right)$.

\subsection{Total mercury in biota}

Scrobicularia plana was found to have higher mercury levels than Hediste diversicolor except for the reference site A15 ( $p<0.01$, one-way ANOVA). Mercury levels in both species were in accordance with environmental contamination, with the higher body burdens found in the Laranjo Basin area (A1-A5) (Fig. 3). In this area, mercury concentrations in $S$. plana ranged from 0.21 to $0.79 \mathrm{mg} \mathrm{kg}^{-1}$ wet weight (up to $1.4 \mathrm{mg} \mathrm{kg}^{-1}$ in one individual sample), which largely exceeded the $0.5 \mathrm{mg} \mathrm{kg}^{-1}$ threshold permitted for human consumption. For the ragworm all levels fell below $0.5 \mathrm{mg} \mathrm{kg}^{-1}$, varying between 0.039 and $0.13 \mathrm{mg} \mathrm{kg}^{-1}$ in the same area. These differences may result from different exposure times (S. plana has a larger lifespan than $H$. diversicolor) and also species-specific traits. Downstream from the contamination source, mercury body burdens were sharply reduced in both species, S. plana oscillating from 0.082 to $0.015 \mathrm{mg} \mathrm{kg}^{-1}$ and $H$. diversicolor between 0.021 and $0.0030 \mathrm{mg} \mathrm{kg}^{-1}$, similar to the reference site and thus considered as background concentrations. Statistics for both species $(p<0.01$, oneway ANOVA with Tukey HSD) discriminated three different contamination scenarios: (1) a very contaminated site (A1); (2) a moderate contaminated area (A2-A5) inside the Laranjo Basin; and (3) a non-contaminated group, corresponding to all sites outside the Laranjo Basin and the reference site (A6A15). This confirmed the confinement of mercury contamination to Laranjo Basin.

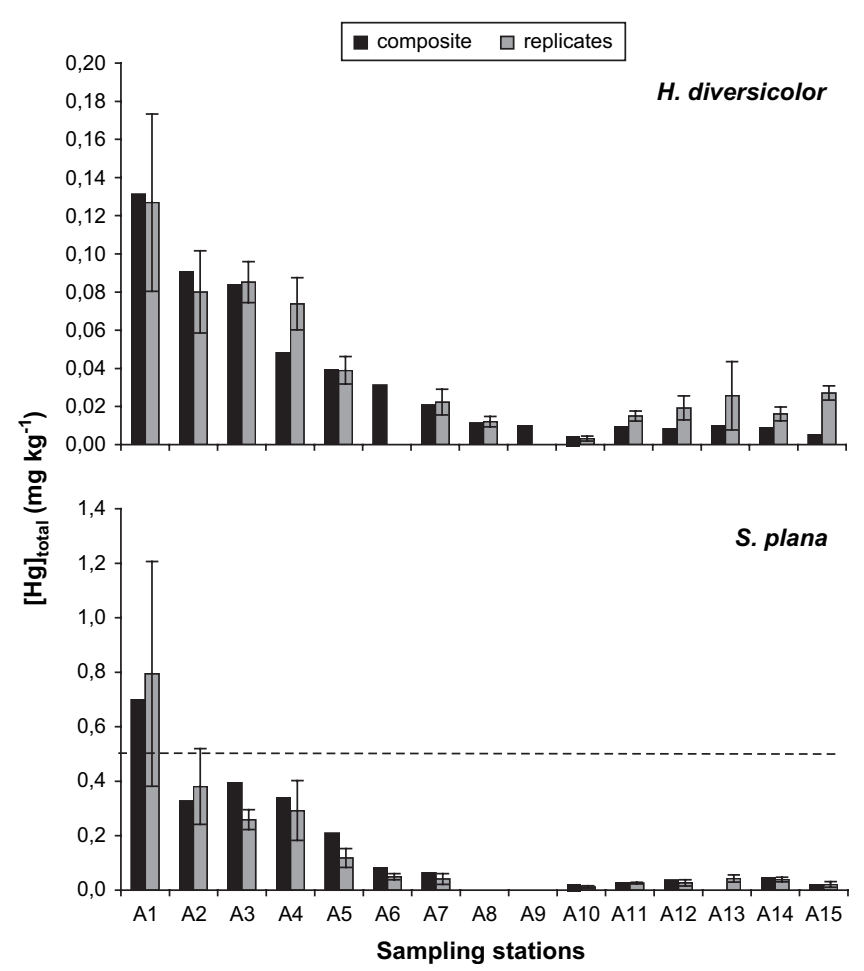

Fig. 3. Total mercury $\left(\mathrm{mg} \mathrm{kg}^{-1}\right)$ in individual replicates $(n=10)$ and composite samples of Scrobicularia plana and Hediste diversicolor (error bars represent standard deviation). 
Composite samples were globally in good agreement with the individual replicates and were therefore considered to be reliable as a measure of contamination (Fig. 3).

\subsection{Mercury partition in biota}

Organic mercury levels were also higher for Scrobicularia plana, ranging from 0.15 to $0.022 \mathrm{mg} \mathrm{kg}^{-1}$ in the contaminated area and between 0.011 and 0.0035 outside the Laranjo Basin (Fig. 4A), while for Hediste diversicolor organic mercury reached $0.056-0.013 \mathrm{mg} \mathrm{kg}^{-1}$ and $0.0057-$ $0.0013 \mathrm{mg} \mathrm{kg}^{-1}$ in the same areas. The organic mercury fraction varied between $5 \%$ and $30 \%$ in S. plana, with an average of $15 \pm 7.1 \%$, significantly lower than in $H$. diversicolor where it ranged from 5\% to $43 \%$, with an average of $27 \pm 10.5 \%(p<0.05$, Wilcoxon Signed Ranks test). No clear pattern was observed for organic mercury fraction between sites, but low and high organic fractions were generally consistent in the two species and highly correlated $(r=0.71$, $p<0.01$, Spearman's correlation), and hence must reflect the bioavailability of organic mercury in each sampling site (Fig. 4B).

\subsection{Annual mercury uptake by biota}

Mercury concentrations in both species were normalized for the average age of the composite sample in order to assess the annual accumulation of these species (Fig. 5). For Hediste
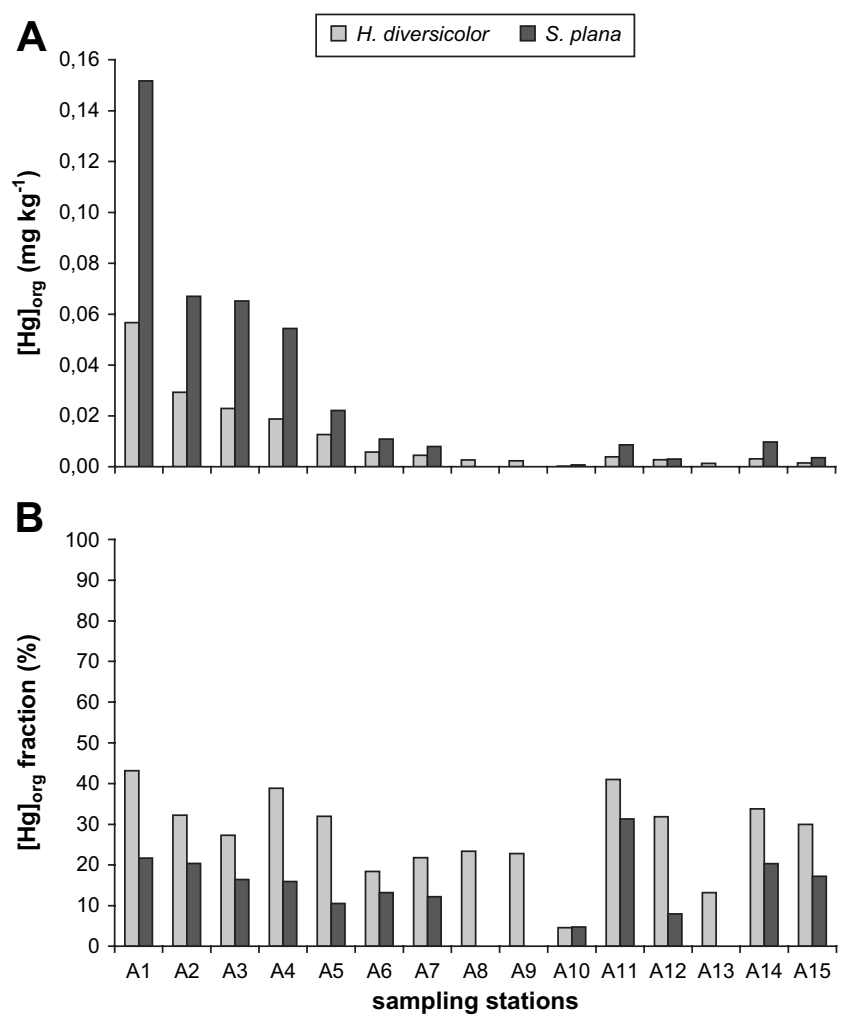

Fig. 4. Organic mercury concentrations $\left(\mathrm{mg} \mathrm{kg}^{-1}\right)$ and organic mercury fraction in composite samples of Scrobicularia plana and Hediste diversicolor.
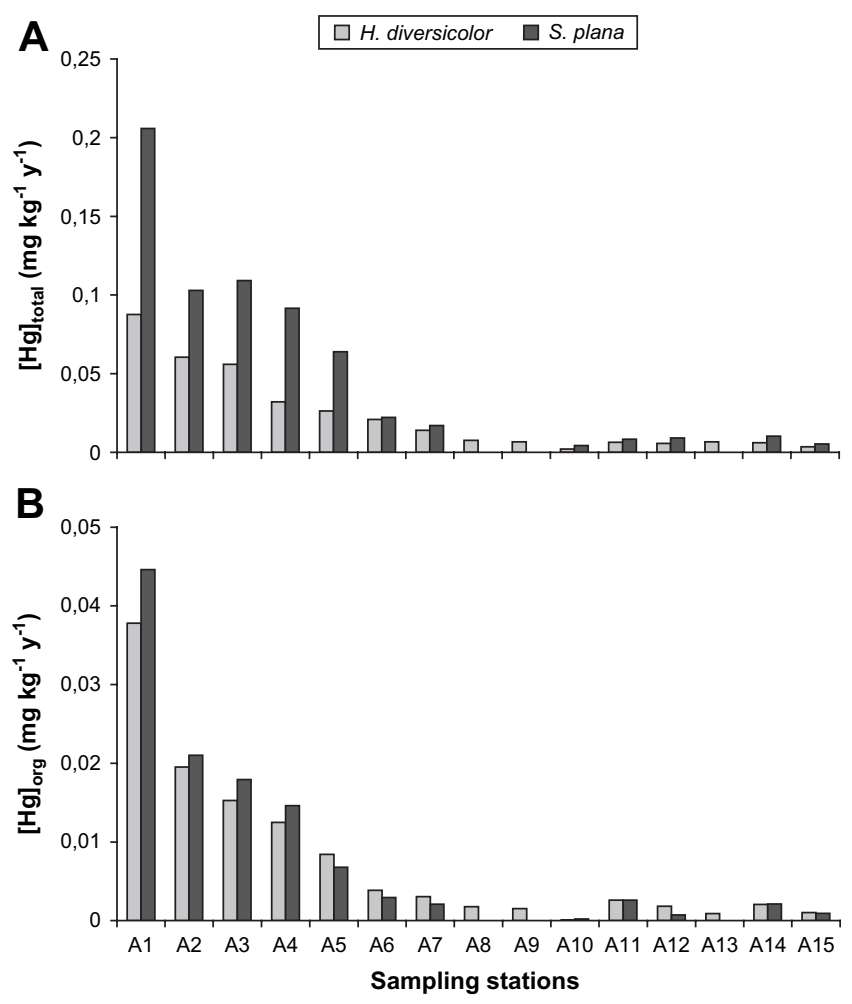

Fig. 5. Annual total mercury (A) and organic mercury (B) accumulation $\left(\mathrm{mg} \mathrm{kg}^{-1} \mathrm{y}^{-1}\right)$ in Scrobicularia plana and Hediste diversicolor.

diversicolor a conservative average age of 1.5 years was assumed, since this species is known to reach a maximum of 2 years in this system (Abrantes et al., 1999), and the size of the individuals in the composite sample was consistent with this age range. For Scrobicularia plana composite samples, individuals were measured and age calculated, since it is known that the growth rate of this species is $\pm 1 \mathrm{~cm} \mathrm{y}^{-1}$. This species was found to accumulate mercury linearly throughout its lifespan (Coelho et al., 2006), with larger clams having larger mercury body burdens and no age associated dilution to occur, and thus average age was used to calculate the overall annual mercury accumulation rate.

The results show that in the most contaminated area (A1-A5), concerning total mercury (Fig. 5A), Scrobicularia plana accumulates significantly ( $p<0.05$, Wilcoxon Signed Ranks test) more mercury than Hediste diversicolor on an annual basis, reaching more than twice the concentration found in the ragworm $\left(0.064-0.21 \mathrm{mg} \mathrm{kg}^{-1} \mathrm{y}^{-1}\right.$ in the bivalve, $0.026-0.087$ $\mathrm{mg} \mathrm{kg}{ }^{-1} \mathrm{y}^{-1}$ in the polychaete). With reduced environmental contamination (A5-A15), inter-species differences fade and a similar pattern is observed $\left(0.0043-0.022 \mathrm{mg} \mathrm{kg}^{-1} \mathrm{y}^{-1}\right.$ for S. plana and $0.0021-0.021 \mathrm{mg} \mathrm{kg}^{-1} \mathrm{y}^{-1}$ for H. diversicolor).

Considering organic mercury, a different scenario was observed, with similar annual mercury loads in both species (0.0010-0.045 mg kg${ }^{-1} \mathrm{y}^{-1}$ in the clam and $0.0010-0.038$ $\mathrm{mg} \mathrm{kg}^{-1} \mathrm{y}^{-1}$ in the ragworm, $p<0.05$, Wilcoxon Signed Ranks test), regardless of environmental contamination, which will eventually result in the higher organic mercury fraction found for Hediste diversicolor (Fig. 5B). 


\subsection{Annual production}

The annual production for both species was calculated in sites with distinct mercury contamination, in order to assess the role of these benthic sediment dwelling invertebrates on the mercury transfer to estuarine food webs. Production was considerably higher for Scrobicularia plana, 3- to 10-fold higher depending on site (Table 1), and highest on the most contaminated area. Taking into consideration the higher mercury levels found in the bivalves, this species was responsible for the bulk mercury removal from the sediment, incorporating as much as $28 \mu \mathrm{g} \mathrm{m}^{-2} \mathrm{y}^{-1}$, of which $5.7 \mu \mathrm{g} \mathrm{m}^{-2} \mathrm{y}^{-1}$ are in organic form, one order of magnitude higher than Hediste diversicolor. Also, such removal was confined to the inner basin, reflected in the sharp decline from locations A2 to A5, approximately $1.6 \mathrm{~km}$ apart. In the remnant of the system, mercury transfer from sediments to biota was residual.

In fact, extrapolating the results from location A2 to the approximate $0.4 \mathrm{~km}^{2}$ of intertidal flats existent in the inner Laranjo Basin (A1-A3), these two communities are responsible for the annual incorporation of $11.5 \mathrm{~g}$ of mercury from the sediments (of which $2.4 \mathrm{~g}$ are in organic form), $95 \%$ by Scrobicularia plana and only $5 \%$ by Hediste diversicolor, which taking into consideration the $10.6 \times 10^{3} \mathrm{~kg}$ of mercury stored in the area (Pereira et al., 1998), seems residual. In the moderately contaminated area (A4-A5), with a much lower intertidal area, the annual mercury budget did not exceed $1 \mathrm{~g}$ (0.12 g in organic form), $93 \%$ for S. plana and $7 \%$ for $H$. diversicolor.

\section{Discussion}

Both species responded to the environmental contamination gradient, and composite samples were considered suitable to characterize the individual contamination at any given site. As a whole, Scrobicularia plana had higher mercury body burdens than Hediste diversicolor, both for total and organic mercury. Considering the longer lifespan of the clam and the knowledge on the lifespan mercury accumulation pattern of this species (Coelho et al., 2006), these results were expected. A clam of 3 years will have been subject to environmental contamination for twice as long as an adult worm (around 18 months old), and considering the linear accumulation pattern found for this species (Coelho et al., 2006), to have higher mercury body burdens would be a reasonable assumption. On

Table 1

Annual production and associated mercury available for trophic transfer in Scrobicularia plana and Hediste diversicolor

\begin{tabular}{|c|c|c|c|c|c|c|}
\hline & $\begin{array}{l}\text { Annual produc } \\
\left(\mathrm{g} \mathrm{DW} \mathrm{m} \mathrm{m}^{-2} \mathrm{y}^{-}\right.\end{array}$ & & Assoc & $\mathrm{ed} \mathrm{Hg}$ & $\mathrm{m}^{-2}$ & \\
\hline & H. diversicolor & S. plana & H. di & sicolor & S. pla & \\
\hline & & & $\mathrm{Hg}_{\text {tot }}$ & $\mathrm{Hg}_{\text {org }}$ & $\mathrm{Hg}_{\text {tot }}$ & $\mathrm{Hg}_{\text {org }}$ \\
\hline A2 & 10.6 & 85.1 & 0.96 & 0.310 & 27.94 & 5.702 \\
\hline A5 & 4.6 & 12.2 & 0.18 & 0.058 & 2.55 & 0.269 \\
\hline A6/A7 & 0.5 & 4.1 & 0.01 & 0.003 & 0.30 & 0.039 \\
\hline A10 & 7 & 68 & 0.02 & 0.001 & 1.03 & 0.048 \\
\hline
\end{tabular}

an annual basis, however, the clam still accumulated higher total mercury amounts than the polychaete, which suggest species-specific ecological and physiological traits and may result from one or a combination of various reasons: considering that most inorganic mercury is accumulated from the sediments (Wang et al., 1998), a higher sediment intake rate from $S$. plana would imply an increased mercury flow through the digestive tract, thus, higher accumulation into the tissues. Also, some research has focused on the assimilation efficiency of several organisms to sediment-associated mercury and the uptake from the dissolved fraction (Wang et al., 1998; Learner and Mason, 2002; Zhong and Wang, 2006), through incubation with gut juices. The assimilation efficiency for both nereids and clams was dependent on sediment contamination, sediment characteristics and contact time between the gut juices and the sediment, but also dependent on species-specific traits. A hypothetical higher mercury assimilation efficiency by $S$. plana when compared to $H$. diversicolor due to more effective gut juices could also explain the increased annual mercury accumulation. However, no information is available on assimilation efficiencies or sediment intake rates for either species to corroborate these hypotheses.

The organic mercury fraction was surprisingly higher in Hediste diversicolor, given the supposedly similar feeding tactics and environmental exposure. While Scrobicularia plana is described in the literature as a surface deposit feeder (Pérez et al., 2004; Verdelhos et al., 2005), H. diversicolor usually behaves as deposit feeder (Moreira et al., 2006), but is considered an omnivore and can actually behave as an active predator (Barnes, 1994; Scaps, 2002; Moreira et al., 2006). Considering the higher organic mercury content of organisms when compared to sediment (usually below 1\%), and that mercury accumulates up the food chain (Lawson and Mason, 1998; Wang et al., 1998), the ragworm dietary opportunism (small invertebrates smaller than itself, scavenger and even pulling small dead fish into its burrow; Barnes, 1994) may be the reason for the elevated organic mercury fraction, due to the higher organic mercury load of such diet. Taking into account that the dissolved fraction can have an important role on organic mercury accumulation (Wang et al., 1998), that the assimilation efficiency of methylmercury in anoxic sediments can reach as high as $80 \%$ (Wang et al., 1998; Zhong and Wang, 2006) and the higher percentage of organic mercury in the anoxic sediment layers, where it reaches as high as $30 \%$ of total mercury in interstitial waters (Gagnon et al., 1996), the fact that both species can reach $30 \mathrm{~cm}$ depth may also result in increased uptake of the bioavailable organic mercury forms. Substantial amounts of methylmercury can exist in the pore waters of anoxic sediment layers, but cannot freely diffuse to the water column, because the superficial oxic sediment layer acts as a geochemical barrier, making it unavailable for accumulation by fauna (Gagnon et al., 1996). From an ecological perspective, our findings may have important implications, taking into consideration that $S$. plana and $H$. diversicolor are among the most common and more abundant benthic invertebrates in temperate climates. Through burrowing activities and mercury uptake in deep and anoxic sediment 
layers, both species enhance the bioavailability of sedimentassociated methylmercury to higher trophic levels, acting as vectors for mercury incorporation in estuarine food webs.

The annual productions of the two species seem to indicate that the mercury levels found in the environment are sub-toxic, since the production was highest in the most contaminated area. The calculations based on the annual secondary production of the two species emphasize the importance of Scrobicularia plana as a vector of mercury transfer from sediments to biota, since it incorporates one order of magnitude more mercury per $\mathrm{m}^{2}$ than Hediste diversicolor in the most impacted area. In fact, S. plana was responsible for nearly $95 \%$ of the mercury budget associated with biological production of sediment dwelling organisms in the Laranjo Basin, which reaches as high as $11.5 \mathrm{~g}$ per year. This amount may seem residual when compared to the mercury stored in the sediments of this confined basin $\left(10.6 \times 10^{3} \mathrm{~kg}\right)$, and the effects of the studied infauna for the global geochemical mercury cycle is unknown. This mercury may be restored to the sediment in the form of decaying organic matter and re-enter the geochemical mercury cycle. Yet it can also be transferred to higher trophic levels by predation and exported to other areas of the system, since $S$. plana and $H$. diversicolor are important prey of estuarine predators such as fish (Leitão et al., 2006), crabs (Baeta et al., 2006) and birds (Lopes et al., 2006). Considering the overall geochemical mercury cycle in the sediments, $12 \mathrm{~g}$ of mercury removed from sediments and incorporated in organisms seems irrelevant, but considering the estuarine food webs and the species living in the vicinity of this area, it may be significant. Previous studies have found the mercury levels of Carcinus maenas (Pereira et al., 2006) and Dicentrarchus labrax (Abreu et al., 2000) specimens captured in this area to exceed the European threshold concentration for fish and seafood $\left(0.5 \mathrm{mg} \mathrm{kg}^{-1}\right.$ for seafood and $1 \mathrm{mg} \mathrm{kg}^{-1}$ for certain fish, EC No. 466/2001), and bearing in mind that both species feed on $S$. plana and $H$. diversicolor, the importance of these findings to the understanding of biomagnification processes is evident.

Taking into account the mercury loads found, clearly exceeding the threshold concentration permitted for human consumption, and the amount of mercury removed from the sediment, Scrobicularia plana can be considered a key species in the mercury biomagnification processes. Scrobicularia plana, itself an important food resource for human population, increases mercury bioavailability and, by predation, transfers it to other economically important and exploited natural resources. Further investigation is needed to better quantify this benthic organism-mediated mercury transfer from an immobile, unavailable form in sediment anoxic layers to highly bioavailable mercury forms by predation on benthic infauna.

\section{Acknowledgements}

This study was supported by the Portuguese Foundation for Science and Technology through the POCTI-2010 Formação
Avançada para a Ciência-Medida IV.3 (Portuguese FCT) via a PhD grant (SFRH/BD/19509/2004) (J.P.C.).

\section{References}

Abrantes, A., Pinto, F., Moreira, M.H., 1999. Ecology of the polychaete Nereis diversicolor in the canal de Mira (Ria de Aveiro, Portugal): Population dynamics, production and oogenic cycle. Acta Oecologica 20, 267-283.

Abreu, S.N., Pereira, E., Vale, C., Duarte, A.C., 2000. Accumulation of mercury in sea bass from a contaminated lagoon (Ria de Aveiro, Portugal). Marine Pollution Bulletin 40, 293-297.

Baeta, A., Cabral, H.N., Neto, J.M., Marques, J.C., Pardal, M.A., 2006. Biology, population dynamics and secondary production of the green crab Carcinus maenas (L.) in a temperate estuary. Estuarine, Coastal and Shelf Science 65, 43-52.

Barnes, R.S.K., 1994. The Brackish-Water Fauna of Northwestern Europe. Cambridge University Press, Cambridge, 287 pp.

Brey, T., 2001. Population dynamics in benthic invertebrates. A virtual handbook. Version 01.2. Alfred Wegener Institute for Polar and Marine Research, Germany. http://www.awi-bremerhaven.de/Benthic/Ecosystem/ FoodWeb/Handbook/main.html (cited November 2005).

Clarkson, T.W., Magos, L., Myers, G.J., 2003. Human exposure to mercury: the three modern dilemmas. The Journal of Trace Elements in Experimental Medicine 16, 321-343.

Coelho, J.P., Rosa, M., Pereira, M.E., Duarte, A., Pardal, M.A., 2006. Pattern and annual rates of Scrobicularia plana mercury bioaccumulation in a human induced mercury gradient (Ria de Aveiro, Portugal). Estuarine, Coastal and Shelf Science 69, 629-635.

Coelho, J.P., Policarpo, E., Pardal, M.A., Millward, G.E., Pereira, M.E., Duarte, A.C., 2007. Mercury contamination in invertebrate biota in a temperate coastal lagoon (Ria de Aveiro, Portugal). Marine Pollution Bulletin $54,475-480$

Dolbeth, M., Lillebø, A.I., Cardoso, P.G., Ferreira, S.M., Pardal, M.A., 2005. Annual production of estuarine fauna in different environmental conditions: An evaluation of the estimation methods. Journal Experimental Marine Biology and Ecology 326, 115-127.

Gagnon, C., Pelletier, E., Mucci, A., Fitzgerald, W.F., 1996. Diagenetic behaviour of methylmercury in organic-rich coastal sediments. Limnology and Oceanography 41, 428-434.

Lawson, N.M., Mason, R.P., 1998. Accumulation of mercury in estuarine food chains. Biogeochemistry 40, 235-247.

Learner, J.J., Mason, R.P., 2002. Factors Controlling the Bioavailability of Ingested Methylmercury to Channel Catfish and Atlantic Sturgeon. Environmental Science and Technology 36, 5124-5129.

Leitão, R., Martinho, F., Neto, J.M., Cabral, H., Marques, J.C., Pardal, M.A., 2006. Feeding ecology, population structure and distribution of Pomatoschistus microps (Krøyer, 1838) and Pomatoschistus minutus (Pallas, 1770) in a temperate estuary. Portugal. Estuarine, Coastal and Shelf Science 66, 231-239.

Lopes, R.J., Pardal, M.A., Múrias, T., Cabral, J.A., Marques, J.C., 2006. Influence of macroalgal mats on abundance and distribution of dunlin Calidris alpina in estuaries: a long-term approach. Marine Ecology Progress Series 323, 11-20.

Miron, G., Brock, V., Kristensen, E., 1994. Effects of mercuryon the ventilation behaviour of the polychaete Nereis virens (Sars). Journal Experimental Marine Biology and Ecology 184, 67-81.

Moreira, S.M., Lima, I., Ribeiro, R., Guilhermino, L., 2006. Effects of estuarine sediment contamination on feeding and on key physiological functions of the polychaete Hediste diversicolor: Laboratory and in situ assays. Aquatic Toxicology 78, 186-201.

Muhaya, B.B., Leermakers, M., Baeyens, W., 1997. Total mercury and methylmercury in sediments and in the polychaete Nereis diversicolor at Groot Buitenschoor (Scheldt estuary, Belgium). Water, Air and Soil Pollution 94, 109-123. 
Pereira, M.E., Duarte, A.C., Millward, G.E., Abreu, S.N., Vale, C., 1998. An estimation of industrial mercury stored in sediments of a confined area of the Lagoon of Aveiro (Portugal). Water Science and Technology 37, 125-130.

Pereira, E., Abreu, S.N., Coelho, J.P., Lopes, C.B., Pardal, M.A., Vale, C., Duarte, A.C., 2006. Seasonal fluctuations of tissue mercury contents in the European shore crab Carcinus maenas from low and high contamination areas (Ria de Aveiro, Portugal). Marine Pollution Bulletin 52, 1450-1457.

Pérez, E., Blasco, J., Solé, M., 2004. Biomarker responses to pollution in two invertebrate species: Scrobicularia plana and Nereis diversicolor from the Cádiz bay (SW Spain). Marine Environmental Research 58, 275-279.

Scaps, P., 2002. A review of the biology, ecology and potential use of the common ragworm Hediste diversicolor (O.F. Müller) (Annelida: Polychaeta). Hydrobiologia 470, 203-218.

Tchounwou, P.B., Ayensu, W.K., Ninashvili, N., Sutton, D., 2003. Environmental exposure to mercury and its toxicopathologic implications for public health. Environmental Toxicology 18, 149-175.

Usero, J., Morillo, J., Garcia, I., 2005. Heavy metal concentrations in molluscs from the Atlantic coast of southern Spain. Chemosphere 59, 1175-1181.

Vale, C., Ferreira, A., Caetano, M., Brito, P., 2002. Elemental composition and contaminants in surface sediments of the Mondego river estuary. In: Pardal, M.A., Marques, J.C., Graça, M.A. (Eds.), Aquatic Ecology of the Mondego River Basin. Global Importance of Local Experience Coimbra. Imprensa da Universidade de Coimbra, pp. 243-256.

Válega, M., Abreu, S., Pato, P., Rocha, L., Gomes, A.R., Pereira, M.E., Duarte, A.C., 2006. Determination of organic mercury in biota, plants and contaminated sediments using a thermal atomic absorption spectrometry technique. Water Air and Soil Pollution 174, 223-234.

Verdelhos, T., Neto, J.M., Marques, J.C., Pardal, M.A., 2005. The effect of eutrophication abatement on the bivalve Scrobicularia plana. Estuarine, Coastal and Shelf Science 63, 261-268.

Wang, W.-X., Fisher, N.S., 1999. Delineating metal accumulation pathways for marine invertebrates. The Science of the Total Environment 237/238, 459-472.

Wang, W.-X., Stupakoff, I., Gagnon, C., Fisher, N.S., 1998. Bioavailability of inorganic and methylmercury to a marine deposit-feeding polychaete. Environmental Science and Technology 32, 2564-2571.

Zhong, H., Wang, W.-X., 2006. Metal-solid interactions controlling the bioavailability of mercury from sediments to clams and sipunculans. Environmental Science and Technology 40, 3794-3799. 